\title{
ANALISIS EVALUASI FORMATIF DALAM PEMBELAJARAN IPA DI KELAS 4 SDN 07 PAGI TEGAL ALUR
}

\author{
Adella ${ }^{1}$, Dwi Setyo Maryanti ${ }^{2}$, Rizkania Fauziyah Rifai ${ }^{3}$ \\ Universitas Muhammadiyah Tangerang \\ adellatriwidodo@gmail.com,dwiyanti26032000@gmail.com
}

\begin{abstract}
Integrated learning must be based on student learning needs. Systematically in its development, it is necessary to have a formative evaluation to improve the quality of instructional programs and to be used as a reference or reference material to improve and improve the content or material of the learning outcomes. Formative evaluation in SDN 07 Pagi Tegal Alur on the subject of 36 students in elementary science learning is done by using test and non-test techniques. The test techniques used are multiple choice and description, non-test techniques using question and answer instruments, discussions, interviews, questionnaires, and observation. The results of the research on the use of formative evaluation in learning science in 4th grade elementary school proved to be effective based on the results of the pre-test and posttest.
\end{abstract}

Keywords: Evaluation, Formative, Natural Sciences, Elementary School

\begin{abstract}
Abstrak: Pembelajaran terpadu harus berbasis pada kebutuhan belajar siswa. Secara sistematis dalam pengembangannya diperlukan adanya evaluasi formatif untuk meningkatkan kualitas program intruksional dan dijadikan pedoman atau bahan acuan untuk memperbaiki dan menyempurnakan isi atau materi hasil belajar tersebut. Pelaksanaan evaluasi formatif di SDN 07 Pagi Tegal Alur pada subjek 36 siswa dalam pembelajaran IPA SD dilakukan dengan teknik tes dan non tes.Teknik tes yang digunakan ialah pilihan ganda dan uraian, teknik nontes menggunakan instrumen tanya jawab, diskusi, wawancara, angket, dan observasi. Hasil dari penelitian penggunaan evaluasi formatif dalam pembelajaran IPA di kelas 4 SD terbukti efektif berdasarkan hasil dari pre-test dan post-test.
\end{abstract}

Kata Kunci: Evaluasi, Formatif, IPA, SD

\section{PENDAHULUAN}

Evaluasi adalah proses merencanakan, memperoleh, melaporkan, dan menggunakan informasi deskriptif dan penilaian tentang manfaat, nilai, signifikansi, dan kebenaran suatu objek dalam rangka memandu pengambilan keputusan, akuntabilitas, dukungan, menyebarkan praktik-praktik yang efektif dan meningkatkan pemahaman tentang fenomena yang terlibat.

Fondatia : Jurnal Pendidikan Dasar

Volume 4, Nomor 1, Maret 2020; 141-149

https://ejournal.stitpn.ac.id/index.php/fondatia 
Menurut buku Metode Riset Evaluasi, Hadi (2011:13) mendefinisikan evaluasi sebagai "proses mengumpulkan informasi mengenai suatu objek, menilai suatu objek, dan membandingkannya dengan kriteria, standar dan indikator"

Dalam proses pengembangan program, jenis evaluasi yang digunakan adalah evaluasi formatif. Evaluasi formatif digunakan ketika suatu produk atau program tertentu sedang dikembangkan dan biasanya dilakukan lebih dari sekali atau continue dengan tujuan untuk melakukan perbaikan secara tepat dan menyeluruh yang mencakup aspek kognitif, afektif, dan psikomotor yang terdapat pada masing-masing siswa. Evaluasi formatif dimaksudkan untuk mendapatkan umpan balik atau feedback. dari peserta didik sehingga pengajar bisa menilai kamampuan siswanya dan dijadikan bahan perbaikan pada kegiatan pembelajaran berikutnya, juga mengetahui kesulitan belajar, hal-hal yang belum di kuasai oleh siswa.

Dalam melakukan evaluasi formatif, pengajar harus memiliki tiga dasar dalam melakukan evaluasi formatif. 1) dasar psikologis, untuk mengetahui sejauh mana tingkat keberhasilan dalam mencapai tujuan. 2) dasar diktatis, untuk menunjukkan bahwa evaluasi sangat besar manfaatnya dan berperan penting dalam memotivasi belajar, mendapatkan informasi atau data siswa yang kesulitan dalam

belajar. 3) dasar administratif, evaluasi diperlukan untuk menentukan Indesks Prestasi, pengisian raport.

Bila pembelajaran di pandang sebagai suatu proses, maka pemebelajaran merupakan rangkaian kegiatan guru dalam rangka mebuat siswa belajar. Proses tersebut dimulai dari merencanakan program pengajaran dan penyusunan persiapan mengajar berikut dengan persiapan perangkat kelengkapannya antara lain berupa alat peraga dan alat alat evaluasi.

Dalam Pembelajaran IPA, guru harus mengembangkan kesadaran siswa tentang adanya hubungan yang saling mempengaruhi antara sains, lingkungan, teknologi, dan masyarakat, serta menghargai alam dan segala keteraturannya. Maka evaluasi formatif berperan penting dalam memenuhi kebutuhan belajar siswa. 


\section{METODE PENELITIAN}

\section{Faktor yang Diteliti}

Siswa : melihat hasil belajar siswa selema pembelajaran berlangsung sebelum dan setelah di adakannya evaluasi formatif

\section{Data dan Sumber Data}

Data yang dikumpulkan dalam penelitian ini adalah :

1. Hasil pekerjaan siswa dalam mengerjakan dalam mengerjakan soal-soal yang diberikan melalui kegiatan pre-test dan post-test

2. Hasil observasi memuat catatan mengenai kegiatan pembelajaran, yang berkaitan dengan siswa

3. Catatan laporan yang memuat catatan obyektif yang berkaitan dengan pembelajaran dari tingkah laku, respon siswa dalam proses pembelajaran yang nantinya akan di evaluasi oleh guru

\section{Teknik Pengambilan Data}

1. Teknik tes :

a. Pilihan ganda dan uraian, merupakan pre-test dan post test.

Pre-test : Tes ini diadakan untuk mengetahui kemampuan awal yang dimiliki siswa sebelum materi diajarkan

Post-test : Tes ini diadakan di akhir pembelajaran setelah materi di ajarkan untuk mengevaluasi kemampuan siswa

2. Teknik nontes :

Menggunakan instrumen

a. Tanya jawab, kegiatan ini dilakukan untuk menstimulus dan membuat siswa merespon serta memberikan feedback atau umpan balik mengenai materi yang disampaikan

b. Diskusi, kegiatan ini dilakukan dalam kelompok antar siswa atau pun diskusi pribadi antara guru dan siswa mengenai materi yang dibahas, dan menanyakan pendapat siswa. 
c. Wawancara, kegiatan ini dilakukan untuk mengetahui kesulitan belajar.

d. Angket, Kegiatan ini diberikan dalam bentuk daftar pertanyaan secara tertulis yang dijawab oleh siswa sebagai responden. Di lakukan untuk memperoleh informasi dari respon tentang kepuasan dalam pembelajaran atau hal-hal yang perlu di tingkatkan.

e. Observasi, pengamatan ini dilakukan saat proses pembelajaran berlangsung untuk menilai tingkah laku, keaktifan dan respon siswa selama pembelajaran.

\section{Indikator Penilaian}

1. Daya Serap Individual

Jumlah skor yang diperoleh siswa x 100\%

Jumlah skor maksimal

2. Ketuntasan Belajar Klasikal (KBK)

Presentase KBK Individu × 100\%

\section{Peserta Tes}

3. Persentase Nilai Rata-rata (NR)

Jumlah skor perolehan x 100\%

Jumlah skor maksimal

4. Observasi :

\begin{tabular}{|c|c|c|c|c|c|c|c|c|}
\hline \multirow{2}{*}{ No } & \multirow{2}{*}{$\begin{array}{l}\text { Kegiatan yang di } \\
\text { observasi }\end{array}$} & \multicolumn{5}{|c|}{ Skala Nilai } & \multirow{2}{*}{$\begin{array}{c}\text { Bobot } \\
\text { Kegiatan }\end{array}$} & \multirow{2}{*}{$\begin{array}{c}\text { Nilai yang } \\
\text { diperoleh } \\
\text { (Nilai x Bobot) }\end{array}$} \\
\hline & & 1 & 2 & 3 & 4 & 5 & & \\
\hline 1 & $\begin{array}{l}\text { Menunjuk bagian-bagian } \\
\text { pada tumbuhan }\end{array}$ & & & & & & 2,5 & \\
\hline 2 & $\begin{array}{l}\text { Menjelaskan fungsi-fungsi } \\
\text { tiap bagian }\end{array}$ & & & & & & 2,5 & \\
\hline
\end{tabular}




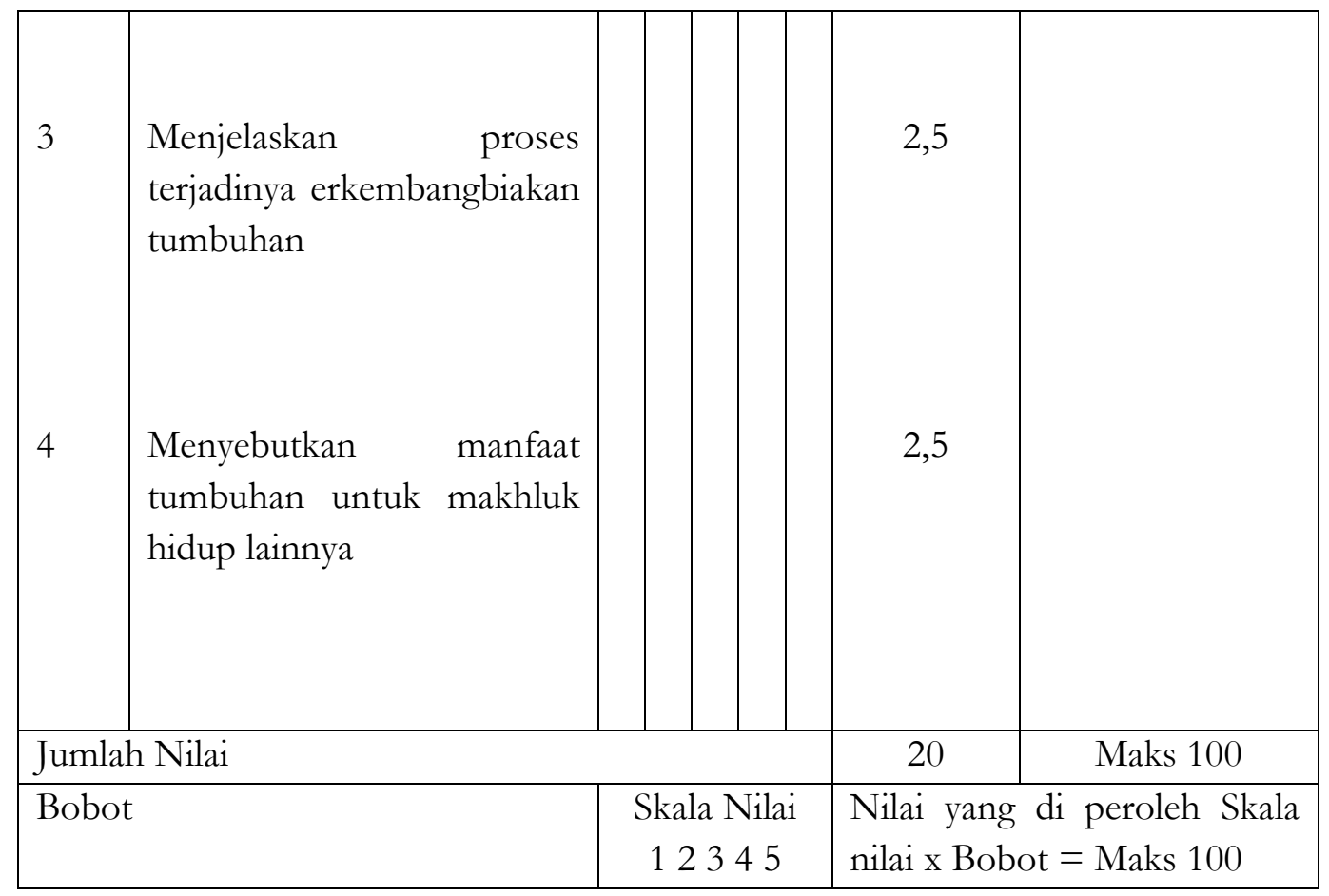

Keterangan Skala Nilai :

$1=$ Sama sekali salah

$2=$ Sebagian besar Salah

$3=$ Sebagian besar benar

$4=$ Hampir sempurna

$5=$ Sempurna

\section{HASIL DAN PEMBAHASAN}

Dalam analisis ini, kegiatan pembelajaran dilakukan sebanyak 2 kali pertemuan sebagai bentuk perbandingan antara hasil pembelajaran yang tidak menggunakan evaluasi formatif dengan pembelajaran yang menggunakan evaluasi formatif dengan keduanya menggunakan instrumen kegiatan pre-test dan post-test.

Setelah dilakukan pembelajaran pertama tanpa menggunakan evaluasi formatif, di dapat hasil guru tidak mengetahui sejauh mana bahan yang telah di ajarkan yang dapat di kuasai oleh peserta didik, hal tersebut dapat menghambat proses 
pembelajaran selanjutnya. Timbulnya rasa kurang percaya diri peserta didik, takut salah, tidak kreatif, dan menurunnya prestasi peserta didik karena tidak adanya penguatan ulang terhadap materi.

Pada pembelajaran kedua, Prosedur atau tahapan evaluasi formatif saat pembelajaran berlangsung di SDN 07 Pagi. Pada 1 jam pembelajaran di awal diadakan pre-test dengan tujuan untuk mengetahui kemampuan awal siswa pada pelajaran IPA materi Struktur bagian Tumbuhan dan fungsinya. Hasilnya ditemukan bahwa pemahaman siswa, secara umum diketahui masih rendah. Kemudian diadakan pemberian materi oleh guru, tanya jawab dan pemberian tugas. Selama proses pembelajaran berlangsung, guru melakukan evaluasi formatif berupa observasi. Di akhir kegiatan guru memberikan penguatan materi kembali kepada siswa agar siap menerima post-test.

Alat evaluasi yang paling tepat diadakan untuk pembelajaran IPA ialah lembar soal pilihan ganda, angket serta tanya jawab dengan media gambar.

Hasil evaluasi setelah di adakannya post-test dengan menggunakan instrumen observasi, tes tulis, angket dan tanya jawab di proses melalui penilaian. Objek penilaian tersebut meliputi :

1. Input, aspek yang bersifat rohani mencakup 4 hal, yaitu :
a. Kemampuan
b. Kepribadian
c. Sikap
d. Inteligensi

2. Transformasi, unsur-unsurnya yaitu :
a. Materi
b. Metode
c. Media dan sarana pendidikan
d. Guru atau personil lainnya 
3. Output, meliputi :

Penilaian terhadap peserta didik untuk mengetahui seberapa jauh tingkat pencapaian/prestasi belajar mereka selama mengikuti program.

Penilaian tersebut menghasilkan bahwa peserta didik siap mengikuti pembelajaran, menyimak apersepsi, menyimak penyampaian tujuan pembelajaran dan terampil dalam penggunaan LKS, menyimak penjelasan materi, keterlibatan siswa dalam KBM, dan antusias dalam proses diskusi.

Keikutsertaan peserta didik dalam mengelola pembelajaran, menunjukkan peningkatan yang sangat signifikan dibandingkan saat pre-test. Setelah post-test berlangsung, peserta didik tampak lebih percaya diri sehingga tidak lagi ragu-ragu dalam menyelesaikan soal.

Dengan demikian dapat di tarik kesimpulan bahwa kegiatan evaluasi formatif setelah dilakukan penilaian melalui pre-test dan post-test yang diadakan dalam pembelajaran IPA di SD kelas 4 dapat meningkatkan hasil belajar peserta didik.

Upaya evaluasi formatif lainnya ialah dengan memberikan umpan balik positif melalui komentar tertulis dapat diberikan pada lembar jawaban ulangan, PR, tugas, atau LKS yang dikerjakan siswa. Guru memberikan umpan balik dengan cara menulis komentar-komentar yang memuat informasi bagaimana seharusnya mereka menjawab soal-soal ulangan, PR, tugas, atau LKS tersebut. Tidak hanya mencoret jawaban-jawaban yang salah dengan tanda silang, tetapi menuliskan langkah-langkah atau jawaban-jawaban yang tepat. Bersamaan dengan pemberian umpan balik, guru memberikan penghargaan (reward) kepada setiap peserta didik untuk tujuan memotivasi belajar peserta didik.

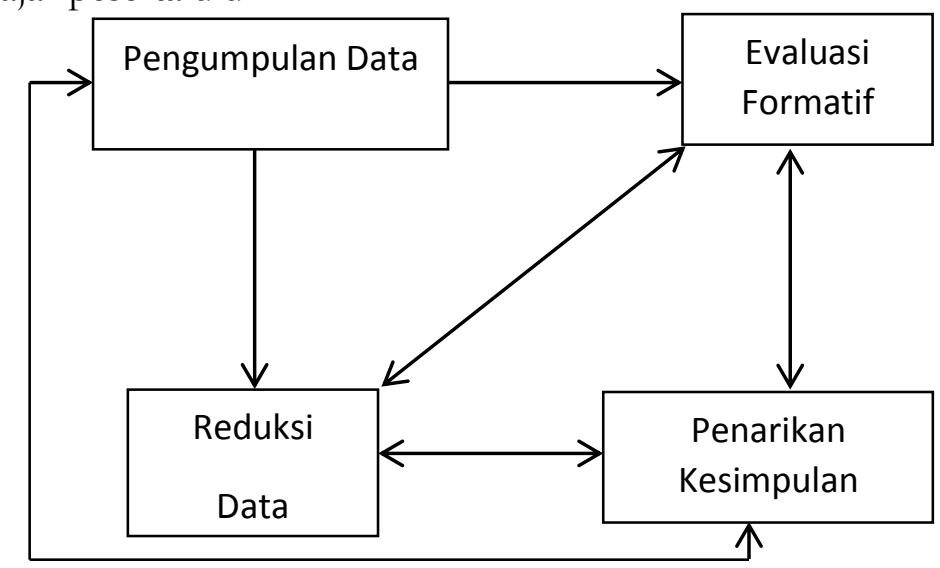


Tahapan akhir evaluasi yang dilakukan guru ialah : Pengumpulan data, reduksi data, evaluasi formatif, dan penarikan kesimpulan. Pengumpulan data dengan membandingkan pre-test dan post-test peserta didik. Untuk peserta didik yang tidak mencapai kriteria ketuntasan minimal (KKM), ditindaklanjuti dengan mencari informasi kelemahan bahan intruksional yang terkait. Tindak lanjut itu berupa wawancara mendalam antara guru dan peserta didik tentang setiap komponen intruksional. Hasil ini diperkuat dengan pendapat peserta didik, kemudian guru menafsirkan pendapat peserta didik tentang kejelasan dan kualitas fisik bahan belajar serta tentang sikap mereka terhadap kegiatan intruksional yang diikutinya merupakan masukan yang harus digunakan untuk memperbaiki produk intruksional terutama pada metode dan media yang digunakan.

Pelaksanaan evaluasi formatif di SDN 07 pagi sudah terjamin terjadinya peningkatan kualitas produk intruksional, karena rekomendasi yang dihasilkan evaluasi itu digunakan untuk merevisi produk intruksional yang di evaluasi tersebut.

Hasil revisi tersebut berbentuk produk intruksional baru. Namun evaluasi formatif kedua tetap perlu dilakukan karena perubahan-perubahan yang dilakukan untuk menghasilkan produk baru tersebut sangat besar dan mendasar, sehingga di perlukan waktu kembali untuk peserta didik melakukan pembiasaan terhadap produk baru tersebut.

Proses yang ideal ialah harus melalui empat tahap evaluasi untuk menghindari kekurangan-kekurangan yang mendasar sebelum prosuk itu digunakan dalam skala besar.

Keempat tahap evaluasi formatif tersebut yaitu:

1. Evaluasi one-to-one oleh para pakar

2. Evaluasi one-to-one oleh peserta didik

3. Evaluasi kelompok kecil

4. Uji coba lapangan 
Bila berbagai pertimbangan yang tidak memungkinkan melakukan keempat tahap tersebut di atas secara lengkap, dapat dipilih salah satu di antara tiga alternatif sebagai berikut:

1. Melaksanakan tiga tahap yang terdiri dari tahap pertama, review ahli isi, tahap kedua, evaluasi satu-satu atau kelompok kecil dan tahap ketiga, uji coba lapangan

2. Melaksanakan dua tahap diantaranya yang terdiri dari review ahli isi di luar tim desain intruksional dan evaluasi kelompok kecil

3. Melakukan dua tahap di antaranya yang terdiri dari review ahli isi di luar tim desain intruksional dan uji coba lapangan.

Informasi yang perlu di kumpulkan untuk setiap tahap harus dirancang dengan rinci dan dilaksanakan dengan cermat.

\section{KESIMPULAN}

Berdasarkan hasil analisis dan pembahasan, maka dapat disimpulkan bahwa terdapat perbedaan yang cukup signifikan pada pokok pembahasan struktur bagian tumbuhan dan fungsinya. Setelah di lakukan analisis terbukti dengan adanya evaluasi formatif hasil belajar siswa menjadi lebih baik daripada siswa yang tidak diberi evaluasi formatif di dalam proses pembelajarannya.

\section{DAFTAR PUSTAKA}

Silverius, S. 1990. Evaluasi hasil belajar dan umpan balik. Jakarta; Grasindo

Suparman, Atwi. 2014. Desain Intruksional Modern. Jakarta; Penerbit Erlangga

Magdalena, Ina., dan Sunaryo. 2017. Bahan Ajar Desain Pembelajaran SD. Jakarta; FKIP UMT Press

Maspupah. 2016. Penerapan Metode Pembelajaran Demonstrasi Untuk Meningkatkan Hasil Belajar Siswa Pada Materi Perkalian Bilangan Cacah di Kelas II SDN Inpres I Birobuli. Jurnal Kreatif Tadulako Online. Vol.4 No.4. 10 Desember 2019: 284-296

Lestariningsih. 2014. Evaluasi Hasil Belajar Siswa Yang Diberi Umpan Balik Positif dan Umpan Balik Negatif Pada Pokok Bahasan Pecahan. Jurnal Pendidikan Matematika STKIP PGRI Sidoarjo. Vol. 2 No. 1. 10 Desember 2019: 65-69 